\title{
Expression of bcl-2 in bladder neoplasms is a cell lineage associated and p53-independent event
}

\author{
Q-L Lu, M Laniado, P D Abel, G W H Stamp, E-N Lalani
}

\begin{abstract}
Aims-To investigate bcl-2 and p53 protein expression in hyperplastic, metaplastic and neoplastic epithelia of the urinary bladder in relation to cell lineages (transitional versus glandular epithelia).

Methods-Formalin fixed, paraffin wax embedded archival tissue blocks of 29 transitional cell carcinomas (TCC), 11 adenocarcinomas, five specimens of cystitis glandularis, four papillomas, and seven samples of morphologically normal bladder mucosa were examined immunohistochemically with antibodies specific to bcl-2 and p53. Consecutive sections were used to assess co-expression of the two proteins.
\end{abstract}

Results-bcl-2 protein was expressed heterogeneously in basal cells of the normal transitional epithelium, whereas p53 was rarely detectable in either normal or hyperplastic epithelium. Of the 29 TCCs, $20(69 \%)$ expressed immunodetectable p53 which was positively associated with grade. In contrast, bcl-2 was detected in four (14\%) TCCs and its expression was not associated with grade. bcl-2 was expressed constitutively in all five specimens of cystitis glandularis and in all adenocarcinomas; p53 was co-expressed in most of the latter. There was no association between bcl-2 and $p 53$ protein expression in the TCCs. Expression of bcl-2 protein correlated negatively with grade of adenocarcinoma.

Conclusion-In bladder adenocarcinomas, bcl-2 expression correlated negatively with tumour grade whereas p53 was associated positively with tumour grade. The association of bcl-2 with cystitis glandularis and adenocarcinoma but not TCC suggests that it may be involved in triggering a lineage switch converting transitional epithelium to a glandular phenotype. (f Clin Pathol: Mol Pathol 1997;50:28-33)

Keywords: bcl-2; p53; cell lineage; differentiation; bladder cancer; transitional cell carcinoma.

Expression of the bcl-2 (B-cell lymphoma/ leukaemia-2) gene confers survival advantage and prevents cell death by apoptosis induced under a variety of suboptimal culture conditions. Over-expression of bcl-2 was detected initially in lymphomas and leukaemias with the $t(14 ; 18)$ chromosome translocation and its oncogenic potential has been supported further by experiments in vitro and in vivo..$^{1-4}$ bcl-2 can co-operate with cellular and viral oncogenes during cell immortalisation or transformation, or both. ${ }^{3-6}$ bcl-2 transgenic mice show polyclonal lymphoid hyperplasia and follicular hyperplasia, evolving into large cell lymphomas in association with c-myc gene rearrangement. ${ }^{7}$ bcl-2/c-myc transgenic mice develop B cell lymphomas much more quickly than c-myc transgenic ones. ${ }^{47}$ Therefore, it has been postulated that bcl-2 expression prolongs the life span of cells, thereby increasing the risk of other genetic changes via mutation or viral infection, resulting in malignant transformation or overt tumour progression. ${ }^{78} \mathrm{bcl}-2$ is also expressed in lymphoid malignancies without $\mathrm{t}(14 ; 18)$ and in normal lymphoid cells. ${ }^{9} 10$

Expression of bcl-2 in normal epithelia is generally restricted to cells within the stem cell compartment, such as basal cells of the squamous epithelium and cells at the base of the crypts in the intestine. ${ }^{11} 12$ The ductular cells of exocrine glands (pancreas, salivary and sweat glands) also express bcl-2. Expression of bcl-2 in epithelial cells seems to be restricted to cells at specific stages of differentiation. ${ }^{12}$ High bcl-2 protein concentrations have been reported in human fetal skin basal cells committed to the development of the hair follicle and in the emerging glandular buds of the mammary gland. ${ }^{12-14}$ Similar results have also been reported in mice. ${ }^{15}$ These observations suggest that the expression of bcl-2 is a highly conserved event involved in the process of epithelial commitment and differentiation.

The expression of bcl-2 in different epithelial malignancies arising from the same organ is variable and cell lineage dependent. ${ }^{16-22}$ In the lung, over twice as many (69\%) small cell carcinomas express bcl-2 compared with a much smaller percentage $(26 \%)$ of non-small cell carcinomas. ${ }^{23}$ Most $(88 \%)$ gastric adenocarcinomas of intestinal type express bcl-2, whereas only a small fraction (7\%) of diffuse type do. ${ }^{24}$ Most importantly, nearly all basal cell carcinomas examined in a study by Verhaegh et $a l^{25}$ were bcl-2 positive in contrast to squamous carcinomas which were all bcl-2 negative. These studies suggest that expression of bcl-2 seems to be dependent on type of tumour cell and its degree of differentiation.

The molecular mechanism underlying bcl-2 gene expression in epithelial malignancies is undefined as yet. However, several recent studies have shown that $\mathrm{p} 53$ is involved in the regulation of bcl-2 expression. ${ }^{26-28}$ p53 has two distinctive functions-inducing $\mathrm{G} 1$ arrest and apoptosis. The pathway by which p53 induces apoptosis is yet to be identified. The involve- 
ment of p53 in the bcl-2 related cell survival pathway was first suggested from the observation that p53 induced cell death was prevented by bcl-2 expression. ${ }^{26}$ Further in vitro studies have demonstrated that p53 down-regulates endogenous bcl-2 expression. ${ }^{27}$ Miyashita $e t a l^{27}$ reported that bcl-2 expression was greatly increased, particularly in the prostatic epithelium of p53-deficient mice. ${ }^{27}$ Furthermore, a p53-dependent negative response element has been identified 5 ' upstream of the bcl-2 gene. ${ }^{28}$ A regulatory effect of p53 on bcl-2 expression has also been suggested in epithelial malignancies. ${ }^{29} 30$

In this study, we investigated the expression of bcl-2 and p53 in normal, hyperplastic and malignant epithelia of the urinary bladder using immunohistochemistry. The aims of this study were (1) to determine the expression of bcl-2, (2) its relation to cell lineages (transitional and glandular epithelia) and (3) the changes in the levels of expression during hyperplastic, metaplastic and neoplastic transformation.

\section{Methods}

SAMPLES

Formalin fixed, paraffin wax embedded tissue blocks of bladder samples accrued over the period 1980-1994 were selected from the archives of the Department of Histopathology, Hammersmith Hospital, London. Samples from 56 patients were examined, comprising 29 transitional cell carcinomas (TCCs; six grade I, 12 grade II, and 11 grade III), 11 adenocarcinomas (three well, six moderately, and two poorly differentiated), five specimens of cystitis glandularis, four papillomas, and seven samples of morphologically normal bladder mucosa. Associated foci of transitional epithelial hyperplasia were found in five of the TCCs. Diagnosis of primary adenocarcinoma of bladder was made on the basis that no other primary adenocarcinoma had been identified in the patients. A locally invasive prostatic carcinoma was excluded by negative immunostaining with antibody directed against prostate specific antigen (PSA) in male patients.

ANTIBODIES AND IMMUNOHISTOCHEMISTRY

Serial sections, $4 \mu \mathrm{m}$ thick, were cut and mounted on 3-aminopropyltriethoxysilane coated slides. Alternate sections were examined to see whether they expressed bcl-2 and p53 proteins by the three step (ABC) peroxidase method. Briefly, dewaxed sections were incubated with $2 \%$ hydrogen peroxide in methanol to block endogenous peroxidase activity, and microwaved at 750 watts for 10 minutes in $0.1 \mathrm{M}$ citrate buffer (pH 6.0). All antibodies were diluted in phosphate buffered saline (PBS, pH 7.2) unless otherwise stated. Following microwaving, sections were incubated for one hour at room temperature with monoclonal antibodies bcl-2/124 (Dako, Glostrup, Denmark; 1 in 15 dilution) for bcl-2, DO7 (Dako; 1 in 200 dilution) for p53, and ER-PR8 for human PSA (Dako; 1 in 100 dilution; male patients only) followed by biotinylated rabbit anti-mouse antibody (Dako; 1 in
200 dilution), and horseradish peroxidase (HRP) conjugated streptavidin (Dako; 1 in 200 dilution). Enzyme activity was developed with 3,3'-diaminobenzidine tetrahydrochloride (DAB; Sigma, Poole, Dorset, UK) and $0.1 \%$ hydrogen peroxide. Sections were counter stained with haematoxylin. Prostatic carcinomas known to express detectable levels of p53 and bcl-2 were used as positive controls. In negative controls the primary antibody was replaced with normal rabbit serum.

The intensity of bcl-2 expression in epithelial cells was determined by comparing expression in the epithelial cells with that observed in the lymphocytes in the same section (internal positive control). Immunostaining was graded as follows: weakly positive ( \pm , weaker than that seen in lymphocytes), positive $(t$, similar intensity to staining in lymphocytes) or strongly positive $(++$, stronger than that seen in lymphocytes). For p53 expression, tumours were graded according to the percentage of positive tumour cells as follows: tumours containing less than $10 \%$ positive nuclei were regarded as weakly positive $( \pm)$; those with more than $20 \%$ positive nuclei as strongly positive $(++)$; and those in the intermediate range as positive $(+)$.

\section{STATISTICAL ANALYSES}

Spearman's rank correlation coefficient was calculated taking into account tied ranks using Social Package for the Statistical Sciences (SPSS), version 6.1 , to assess the association between tumour grade and expression of either bcl-2 or p53. These are expressed with their respective probability values and $95 \%$ confidence intervals (CI). Co-expression of p53 and bcl-2 was assessed using McNemar's test for paired proportions. Unpaired proportions are described using the normal approximation to the Binomial distribution.

\section{Results}

bcl-2 EXPRESSION

Normal transitional epithelium

Only the basal and occasional suprabasal cells expressed bcl-2 in morphologically normal transitional epithelium in the seven samples of normal mucosa. Three distinct patterns of expression were observed: (1) areas with expression in the majority $(>50 \%)$ of basal cells; (2) areas totally devoid of bcl-2; and (3) only a small proportion of positive cells among a mainly negative basal cell population. These patterns were often seen in different areas of the same sample, but patterns (2) and (3) predominated. The intensity of staining in the basal cells was comparable with that found in lymphocytes.

\section{Hyperplastic transitional epithelium and papillomas}

The three patterns $(1-3)$ described in the previous paragraph were also observed in foci of hyperplastic transitional epithelium in which pattern (3) predominated. Only two of the four papillomas examined contained some focally positive basal cells and the intensity in these cells was less than that observed in the control 


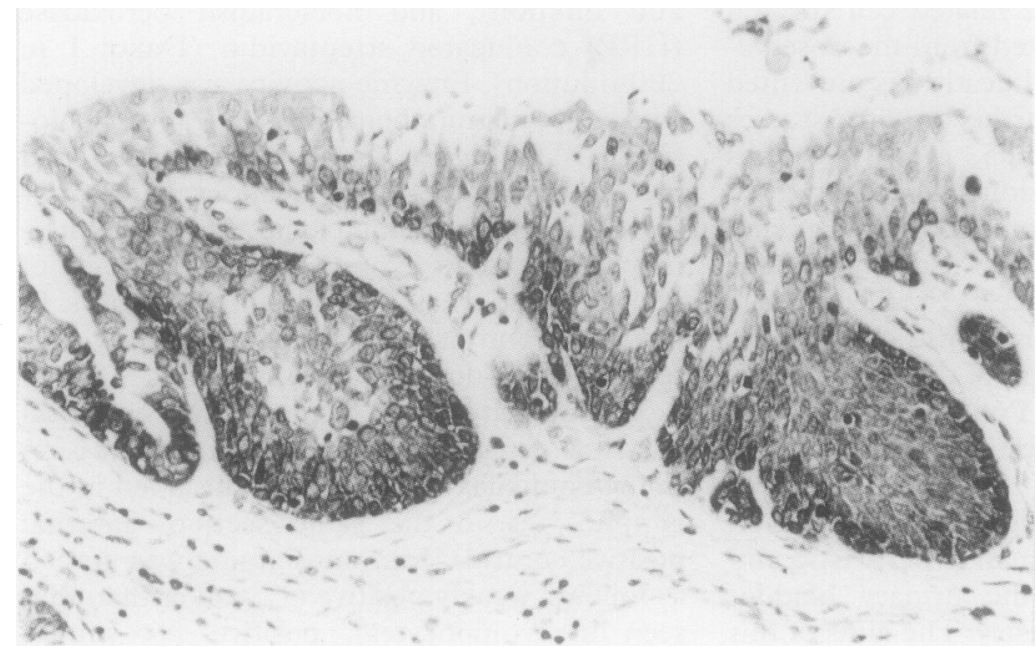

Figure 1 bcl-2 expression in transitional epithelium with hyperplasia. Expression of bcl-2 is mainly localised to the basal layer cells of the surface epithelium, but strong immunoreactivity is observed in nearly all cells of hyperplastic epithelial buds in lamina propria (inverted papilloma). (Immunoperoxidase; original magnification, $\times 200$.)

lymphocytes. By contrast, the majority of basal and suprabasal epithelial cells in the three inverted papillomas stained intensely $(++)$ for bcl-2 (fig 1).

\section{Cystitis glandularis}

Glandular epithelial cells in all five samples of cystitis glandularis expressed bcl-2. In two $(40 \%)$ samples, high concentrations of bcl-2 protein were detected (table 1). All foci of transitional epithelial hyperplasia in samples containing cystitis glandularis were negative. This was clearly demonstrated in one of the samples in which the two (transitional epithelial hyperplasia and cystitis glandularis) were juxtaposed (fig 2A).

\section{Transitional cell carcinomas}

Only $14 \%$ (four of 29 ) of the TCCs weakly expressed bcl-2 (table 1). There was no correlation between expression and grade $(\mathrm{R}=-0.21,95 \% \mathrm{CI}-0.54$ to $0.17, \mathrm{p}=0.27)$. However, in two TCCs there was intense focal bcl-2 expression which contrasted sharply with the predominantly negative surrounding tumour (fig 3).

\section{Adenocarcinomas}

All 11 adenocarcinomas expressed bcl-2 protein (table 1). The level of expression was maximal in the well differentiated tumours and decreased in the poorly differentiated ones
$(\mathrm{R}=-0.77, \mathrm{p}=0.005,95 \%$ CI -0.32 to -0.94 ) (fig $4 \mathrm{~A}$ ).

\section{p53 EXPRESSION}

Normal transitional epithelium and papillomas No detectable p53 expression was identified in morphologically normal transitional epithelium. An occasional cell with weakly positive nuclear staining was noted in the hyperplastic transitional epithelium and in the inverted papillomas. In two of the four papillomas heterogeneous, weak expression of p53 was observed in less than $5 \%$ of the cells.

\section{Cystitis glandularis}

p53 was expressed in only one of the five samples of cystitis glandularis. In this sample nuclear p53 expression was found sporadically in glandular epithelial cells with no expression in the adjacent hyperplastic transitional epithelium (fig 2B).

\section{Transitional cell carcinomas}

Nuclear p53 was detected in $69 \%(20 / 29)$ of the TCCs. The number of $\mathrm{p} 53$ positive nuclei increased with grade $(\mathrm{R}=0.44, \mathrm{n}=29, \mathrm{p}=$ $0.016,95 \%$ CI $0.1-0.70$; table 1$)$. Intense expression (++) was noted in $45 \%$ (five of 11 ) of grade III TCCs, $18 \%$ (two of 12) of grade II TCCs, and in none of the grade I TCC samples.

\section{Adenocarcinomas}

p53 was detected in $90 \%$ of the samples: weak to moderate expression was seen in $64 \%$ (seven of 11 ) and intense expression in $26 \%$ (three of 11). The association between grade and intensity of p53 staining was weak and nonsignificant $(R=0.25, n=11, p=0.43,95 \%$ $\mathrm{CI}-0.41$ to 0.74$)$. Intense p53 immunoreactivity was seen in two poorly differentiated adenocarcinomas but only in one of nine moderately and well differentiated adenocarcinomas (table 1 and fig 4).

\section{AsSOCIATION OF bcl-2 WITH p53 EXPRESSION}

Papillomas and TCCs

There was no correlation between bcl-2 and p53 expression in papillomas and TCCs $(p=0.51)$. Of the four TCCs which expressed bcl-2, $50 \%$ were either positive or negative for p53. Similarly, in 25 bcl-2 negative samples, seven tumours showed no p53 expression and the other 18 tumours expressed p53. The dis-

Table 1 Expression of bcl-2 and p53 in bladder neoplasms

\begin{tabular}{|c|c|c|c|c|c|c|c|c|c|c|}
\hline \multirow[b]{2}{*}{ Histological types and grading } & \multicolumn{4}{|c|}{$b c l-2$} & \multirow{2}{*}{$\begin{array}{l}\text { Total } \\
\text { positivity } \\
\text { (\%) }\end{array}$} & \multicolumn{4}{|c|}{$p 53$} & \multirow{2}{*}{$\begin{array}{l}\text { Total } \\
\text { positivity } \\
(\%)\end{array}$} \\
\hline & - & \pm & + & ++ & & - & \pm & + & ++ & \\
\hline Papilloma & 3 & 1 & 0 & 0 & 25 & 2 & 2 & 0 & 0 & 50 \\
\hline \multicolumn{10}{|l|}{ TCC } & 20 \\
\hline Grade I & 4 & 2 & 0 & 0 & 33 & 4 & 2 & 0 & 0 & 33 \\
\hline Grade II & 11 & 1 & 0 & 0 & 8 & 3 & 4 & 3 & 2 & 75 \\
\hline Grade III & 10 & 1 & 0 & 0 & 9 & 2 & 3 & 1 & 5 & 82 \\
\hline Total no. & 25 & 4 & 0 & 0 & 14 & 9 & 9 & 5 & 6 & 69 \\
\hline \multicolumn{11}{|l|}{ Adenocarcinoma } \\
\hline Well differentiated & 0 & 0 & 1 & 2 & & 0 & 1 & 1 & 1 & \\
\hline Moderately differentiated & 0 & 3 & 3 & 0 & . & 1 & 2 & 3 & 0 & \\
\hline Poorly differentiated & 0 & 2 & 0 & 0 & & 0 & 0 & 0 & 2 & \\
\hline Total no. & 0 & 5 & 4 & 2 & 100 & 1 & 3 & 4 & 3 & 90 \\
\hline
\end{tabular}



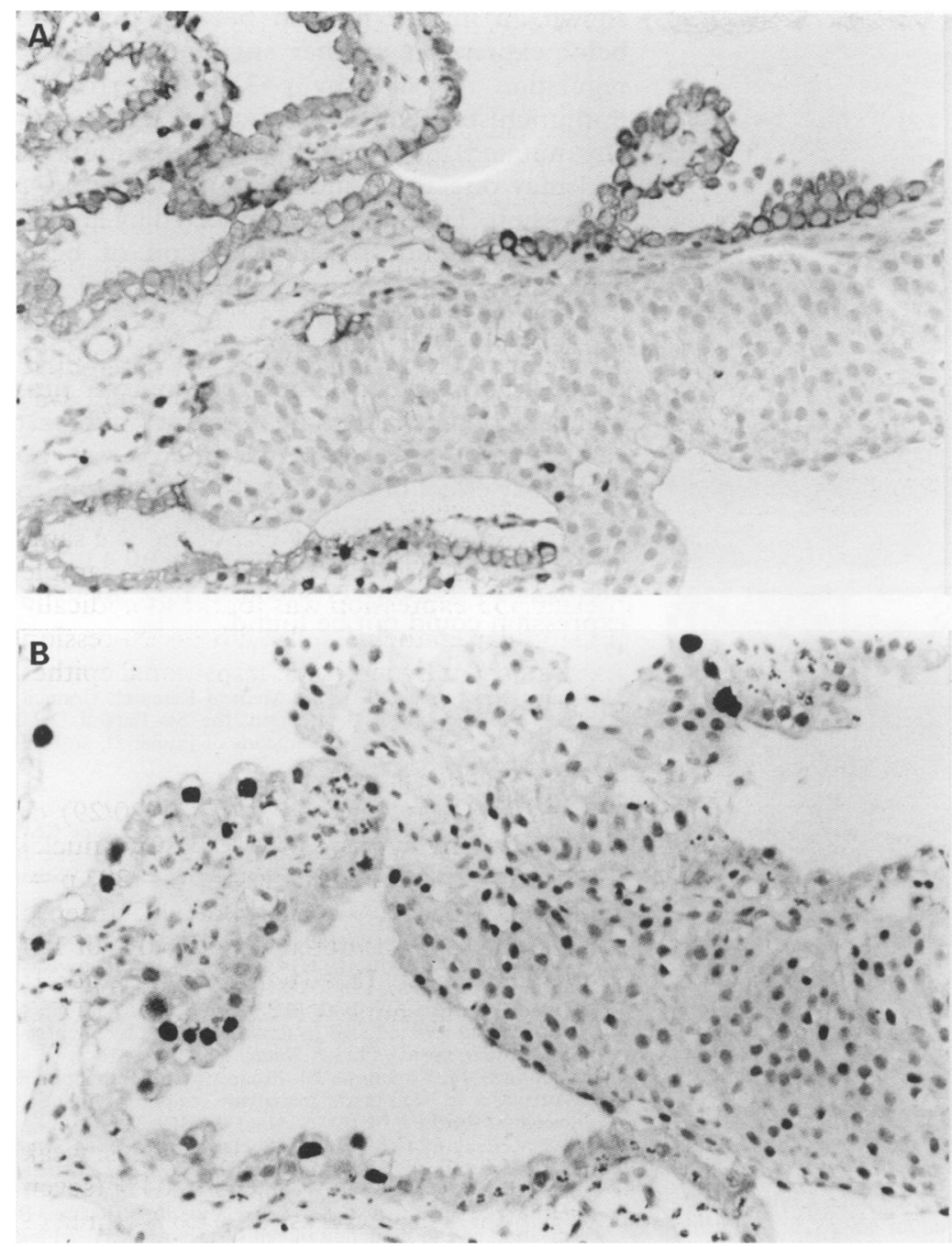

Figure 2 bcl-2 and p53 expression in glandular hyperplasia. (A) bcl-2 is homogeneously expressed in the epithelial cells of glandular hyperplasia, whereas interdigitating hyperplastic transitional epithelium is bcl-2 negative. (B) Nuclear staining for p53 is localised sporadically to the glandular epithelial cells, but not observed in hyperplastic transitional epithelium. (Immunoperoxidase; original magnification, $\times 200$.)

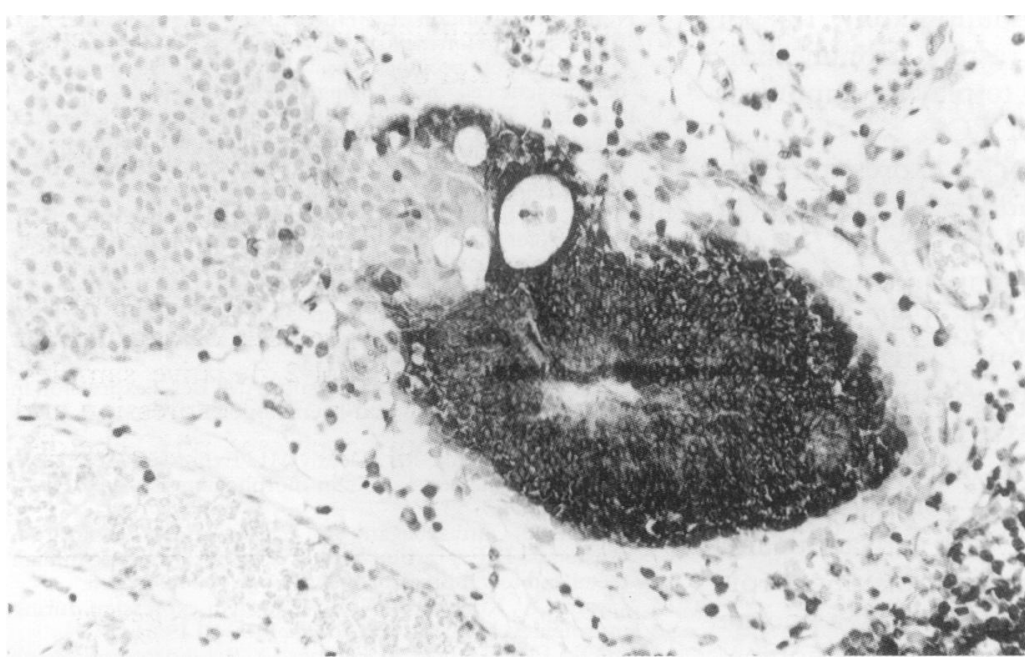

Figure 3 bcl-2 expression in a grade I TCC. Strong immunoreactivity for bcl-2 is limited to cells of one epithelial bud, which cannot be distinguished morphologically from the surrounding bcl-2 negative tumour cells. (Immunoperoxidase; original magnification, $\times 200$.)

tribution patterns of $\mathrm{p} 53$ or bcl-2 positive cells were distinctive: bcl-2 expression was situated basally and distributed focally, whereas p53 positive cells were distributed relatively randomly among the tumour cell population.

\section{Cystitis glandularis and adenocarcinoma}

In only one cystitis glandularis sample was co-expression of bcl-2 and p53 found. In this sample the glandular epithelial cells which expressed p53 also expressed bcl-2, whereas the foci of hyperplastic transitional epithelium were negative for both proteins (figs $2 \mathrm{~A}$ and 2B).

Most of the adenocarcinomas co-expressed bcl-2 and p53. Generally, the level of expression of these two proteins was inversely related: stronger staining for bcl-2 was more apparent in well differentiated and less apparent in poorly differentiated tumours. In contrast, p53 immunoreactivity was less apparent in well differentiated and more apparent in poorly differentiated tumours (table 1). However, in one well differentiated tumour sample coexpression of high levels of bcl-2 and p53 was noted. Both proteins were expressed within the same tumour cells as demonstrated by staining on consecutive sections which showed that bcl-2 was expressed in nearly all cells and p53 in more than $50 \%$ of cells (figs $4 \mathrm{~A}$ and $4 \mathrm{~B}$ ).

\section{Discussion}

During human and murine embryonic development, high concentrations of bcl-2 protein are found in the basal cells of the developing hair follicles and in the epithelial buds of the mammary gland. ${ }^{12-15}$ From these observations an association between bcl-2 and normal epithelial morphogenesis has been suggested. ${ }^{31}$ In this study, we found that bcl-2 was strongly expressed in the epithelial cells of inverted papillomas and in samples of cystitis glandularis, whereas the surface transitional epithelium was mainly bcl-2 negative. The patterns of expression observed in the inverted papillomas and cystitis glandularis are similar to those observed in the developing hair follicle and in the epithelial buds of the mammary gland. ${ }^{12}$ These observations suggest that bcl-2 expression may be a conserved event associated with glandular morphogenesis.

Cystitis glandularis is regarded by some authors as a premalignant lesion and there are several reports in the literature of its conversion to adenocarcinoma. ${ }^{32-35}$ This hypothesis is supported in part by the results of this study. All samples of cystitis glandularis and adenocarcinoma examined in this study expressed high levels of immunodetectable bcl-2. We also found that bcl-2 expression correlated negatively with tumour grade in adenocarcinomas $(p=0.005)$. As bcl-2 expression confers a survival advantage to cells under a variety of stressful conditions and has been implicated as an early event in gastrointestinal and respiratory tract malignancies, ${ }^{36-38}$ we postulate that high levels of bcl-2 may be an initiating event conferring a survival advantage for the development of cystitis glandularis, and potentiating further promoting events necessary in the development of frank malignancy.

Is bcl-2 expression an early event in the evolution of TCCs? Our results suggest that activation of the bcl-2 gene is not a key event in the development of TCCs as we did not observe bcl-2 over-expression in either hyper- 

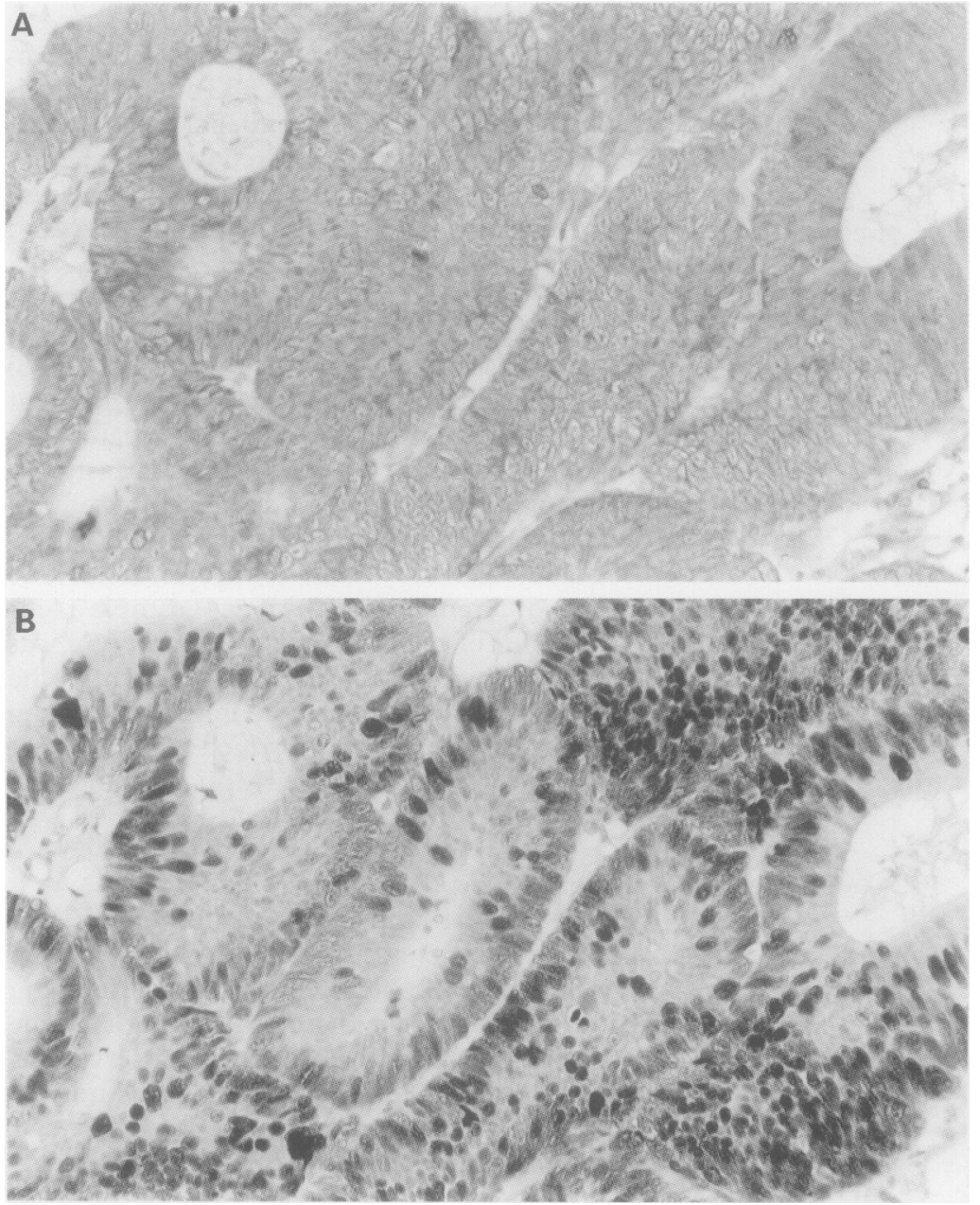

Figure 4 bcl-2 and p53 expression in a well differentiated adenocarcinoma. Consecutive sections were stained for bcl-2 and p53. All tumour cells are stained for bcl-2 (A). Intensive immunoreactivity is observed in the nuclei of the majority of tumour cells $(B)$.

(Immunoperoxidase; original magnification, $\times 200$.)

plastic transitional epithelium or transitional cell papillomas, both of which are recognised as precursors of TCC. Furthermore, heterogeneous bcl-2 expression was found in only $14 \%$ of TCCs examined. These results strongly indicate that bcl-2 is unlikely to play an important role in the development of TCC.

Thus, two patterns of bcl-2 expression have been demonstrated in bladder carcinomas: (1) high prevalence in glandular lesions of the bladder (cystitis glandularis and adenocarcinomas and (2) low prevalence in TCC and associated premalignant lesions. This was most clearly demonstrated in one case with cystitis glandularis and adjacent hyperplastic transitional epithelium, in which high bcl-2 expression was seen in the glandular component only. Our observations suggest that activation and expression of the bcl-2 gene in transitional epithelium may be involved in triggering a lineage switch converting it to a glandular phenotype.

Little is known about the regulation of bcl-2 expression in normal and neoplastic epithelium. The regulatory effect of p53 on the expression of bcl-2 is controversial. bcl-2 expression has been shown to be raised in epithelial cells of p53 deficient mice, suggesting that bcl-2 may be negatively regulated by $\mathrm{p} 53 .{ }^{27}$ Several studies examining p53 and bcl-2 expression in breast adenocarcinomas have shown an inverse relation between p53 and bcl-2 expression, further suggesting negative regulation of bcl-2 by $\mathrm{p} 53 .^{18-20}$ As strongly immunohistochemically detectable p53 is usually mutated, these results suggest that mutated p53 may directly or indirectly modulate bcl-2 expression. This has been supported by Haldar et al who demonstrated inhibition of bcl-2 expression in a mammary epithelial cell line transfected with mutant $\mathrm{p} 53{ }^{30}$ In contrast Daidone $e t a l^{\beta 9}$ observed no change in bcl-2 protein concentrations when p53 expression was dramatically reduced after chemotherapy in breast carcinomas, suggesting that there was no inhibitory effect of p53 on bcl-2 expression. In this study, there was no clear correlation between bcl- 2 and p53 expression and a possible negative regulatory effect of p53 on bcl-2 expression could not be found.

This study was supported by the Medical Research Council, Stanley Thomas Johnson Foundation, the Sir Ratanji Dalal Scholarship (Royal College of Surgeons of England), and the British Medical Association.

1 Tsujimoto Y, Finger LR, Yunis J, Nowell PC, Croce CM. Cloning of the chromosome breakpoint of neoplastic B cells with the $t(14,18)$ chromosome translocation. Science 1984;226: 1097-9.

2 Ngan BY, Chen-Levy Z, Weiss LM, Warnke RA, Cleary ML. Expression in non-Hodgkin's lymphoma of the bcl-2 protein associated with the $t(14 ; 18)$ chromosomal translocation. $N$ Engl f Med 1988;318:1638-44.

3 Strasser A, Harris AW, Bath ML, Cory S. Novel primitive lymphoid tumors induced in transgenic mice by cooperation between myc and bcl-2. Nature 1990;348:331-3.

4 McDonnell TJ, Korsmeyer SJ. Progression from lymphoid hyperplasia to high-grade malignant lymphoma in mice transgenic for the $t(14 ; 18)$. Nature 1991;349:254-6.

5 Rowe M, Peng-Pilon M, Huen DS, Hardy R, Croom-Carter $\mathrm{D}$, Lundgren $\mathrm{E}$, et al. Upregulation of bcl-2 by the EpsteinBarr virus latent membrane protein LMP1: a B-cellBarr virus latent membrane protein LMP1: a B-cell-
specific response that is delayed relative to NF-kappa B activation and to induction of cell surface markers. $₹$ Virol 1994;68:5602-12.

6 Finke J, Lange W, Mertelsmann R, Dolken G. Bcl-2 induction is part of the strategy of Epstein-Barr virus. Leuk Lymphoma 1994;12:413-9.

7 McDonnell TJ, Deane N, Platt FM, Nunez G, Jaeger U, McKearn JP, et al. bcl-2-immunoglobulin transgenic mice demonstrate extended $\mathbf{B}$ cell survival and follicular lymphoproliferation. Cell 1989;57:79-88.

8 Nunez $G$, London $L$, Hockenbery $D$, Alexander $M$ McKearn JP, Korsmeyer SJ. Deregulated Bcl-2 gene expression selectively prolongs survival of growth factor deprived hemopoietic cell lines. F Immunol 1990;144:3602-10.

9 Pezzella F, Tse AGD, Cordell JL, Pulford KAF, Gatter KC, Mason DY. Expression of the bcl-2 oncogene protein is not specific for the $14 ; 18$ chromosomal translocation. $A m \mathcal{F}$ Pathol 1990;137:225-32.

10 Zutter M, Hockenbery D, Silverman GA, Korsmeyer SJ. Immunolocalization of the $\mathrm{Bcl}-2$ protein within hematopoietic neoplasms. Blood 1991;78: 1062-8.

11 Hockenbery DM, Zutter $M$, Hickey W, Nahm M, Korsmeyer SJ. BCL-2 protein is topographically restricted in tissues characterized by apoptotic cell death. Proc Nat Acad Sci USA 1991;88:6961-5.

$12 \mathrm{Lu}$ QL, Poulson R, Wong L, Hanby AM. Bcl-2 expression in adult and embryonic non-haematopoietic tissues. $\mathcal{F}$ Patho 1993;169:431-7.

13 Lebrun DP, Warnke RA, Clearly ML. Expression of Bcl-2 in fetal tissues suggests a role in morphogenesis. Am f Pathol 1993;142: 743-53.

14 Nathan B, Anbazhagan R, Clarkson P, Bartkova J, Gusterson B. Expression of BCL-2 in the developing human foetal and infant breast. Histopathology 1994;24:73-6.

15 Navack DV, Korsmeyer SJ. Bcl-2 protein expression during murine development. Am $\mathcal{F}$ Pathol 1994;145:61-73.

16 Lu QL, Elia E, Lucas S, Thomas JA. Bcl-2 proto-oncogene expression in Epstein-Barr-virus-associated nasopharyngeal carcinoma. Int $\mathcal{f}$ Cancer 1993;53:29-35.

17 Colombel M, Symmans F, Gil S, O'Toole KM, Chopin D, Benson $\mathrm{M}$, et al. Detection of the apoptosis-suppressing oncoprotein $\mathrm{Bcl}-2$ in hormone-refractory human prostate cancers. Am f Pathol 1993;143:390-400.

18 Gee JMW, Roberson JFR, Ellis IO, Willsher P, McClelland RA, Hoyle HB, et al. Immunocytochemical localization of Bcl-2 protein in human breast cancer and its relationship to a series of procnostic markers and response to ensip to a series of prognostic markers and
therapy. Int $\mathcal{F}$ Cancer 1994;59:1-6.

19 Joensuu H, Pylkkanen L, Toikkanen S. Bcl-2 protein expression and long-term survival in breast cancer. $A m \mathcal{F}$ Pathol 1994;145:1191-8. (1) $\overrightarrow{0}$ V

\section{ํํ.} 3

\section{음}


20 Bhargava V, Kell DL, van de Rijn M, Warnke RA. Bcl-2 immuno-reactivity in breast carcinoma correlates with hormone receptor positivity. Am $\mathcal{F}$ Pathol 1994;145:535-40.

21 Pezzella F, Turley H, Kuzu I, Tungekar MF, Dunnill MS Pierce CB, et al. Bcl-2 proto-oncogene in non-small-cell Pierce CB, et al. Bcl-2 proto-oncogene in non-
lung carcinoma. N Engl $\mathscr{f}$ Med 1993;329:690-4.

22 Lauwers GY, Scott GV, Hendricks J. Immunohistochemical evidence of aberrant $\mathrm{Bcl}-2$ protein expression in gastric epithelial dysplasia. Cancer 1994;73:2900-4.

23 Higashiyma M, Doi O, Kodama K, Yokouchi M, Tateishi R. High prevalence of Bcl-2 oncoprotein expression in smallcell lung cancer. Anticancer Res 1995;15:503-5.

24 Lauwers GY, Scott GV, Karpeh MS. Immunohistochemical evaluation of $\mathrm{Bcl}-2$ protein expression in gastric adenocarcinomas. Cancer 1995;75:2209-13.

25 Verhaegh MEJM, Sanders CJG, Arends JW, Neumann HAM. Expression of the apoptosis-suppressing protein HAM. Expression of the apoptosis-suppressing protein Bcl-2 in non-m

26 Wang Y, Szekely L, Okan I, Klein G, Wiman KG. Wild-type p53-triggered apoptosis is inhibited by $\mathrm{Bcl}-2$ in a V-myc-induced T-cell lymphoma line. Oncogene 1993;8: 3427-31.

27 Miyashita T, Krajewski S, Krajewska M, Wang HG, Lin HK, Liebermann DA et al. Tumour suppressor $\mathrm{p} 53$ is a regulator of bcl-2 and bax gene expression in vitro and in regulator of bcl-2 and bax gene
vivo. Oncogene 1994;9:1799-805.

28 vivo. Oncogene $1994 ; 9: 1799-805$. of a p53-dependent negative response element in the bcl-2 of a p53-dependent negative response
gene. Cancer Res 1994;54:3131-5.

29 Selvakumaran M, Lin HK, Miyashita T, Wang HG, Krajewski S, Reed JC, et al. Immediate early up-regulation of bax expression by $\mathrm{p} 53$ but not TGF beta 1: a paradigm for distinct apoptotic pathways. Oncogene 1994;9:1791-8.
30 Haldar S, Negrini M, Monne M, Sabbioni S, Croce CM. Down-regulation of bcl-2 by $\mathrm{p} 53$ in breast cancer cells. Cancer Res 1994;54:2095-7.

31 Lu PJ, Lu QL, Rughetti A, Taylor-Papadimitriou J. Bcl-2 over-expression inhibits cell death and promotes the morphogenesis, but not tumorigenesis of human mammary epithelial cells. f Cell Biol 1995;129:1363-78.

32 Edwards PD, Hurm RA, Jaeschke WH. Conversion of cystitis glandularis to adenocarcinoma. $\mathcal{F}$ Urol 1972;108:568-70.

33 Thrasher JB, Rajan RR, Perez LM, Humphrey PA, Anderson EE. Cystitis glandularis. Transition to adenocarcinoma of the urinary bladder. NC Med f 1994;55:562-4.

34 Channer JL, Williams JL, Henry L. Villous adenoma of the bladder. $\mathcal{f}$ Clin Pathol 1993;46:450-2.

35 Heyns CF, De Kock ML, Kirsten PH, van Velden DJ. Pelvic lipomatosis associated with cystitis glandularis and adenocarcinoma of the bladder. $\mathcal{F}$ Urol 1991;145:364-6.

36 Bronner MP, Culin C, Reed JC, Furth EE. The bcl-2 protooncogene and the gastrointestinal epithelial tumour progression model. Am F Pathol 1995;146:20-6.

37 Walker C Robertson I Myskow M, Dixon G. Expression of the Bcl-2 protein in normal and dysplastic bronchial epithelium and in lung carcinomas. Br $\mathcal{F}$ Cancer 1995;72: 164-9.

38 Bosari S, Moneghini L, Graziani D, Lee AKC, Murray JJ, Coggi G, et al. Bcl-2 oncoprotein in colorectal hyperplastic polyps, adenomas and adenocarcinomas. Hum Pathol 1995;26:534-40.

39 Daidone MG, Silvestrini R, Luisi A, Mastore M, Benini E, Veneroni S, et al. Changes in biological markers after primary chemotherapy for breast cancers. Int $\mathcal{f}$ Cancer 1995;61:301-5. 